\title{
Cytotoxic Effect of Caralluma fimbriata against Human Colon Cancer Cells
}

\author{
Shenai Ashwini, Devaraj Ezhilarasan, Roy Anitha*
}

Shenai Ashwini, Devaraj Ezhila-

rasan, Roy Anitha*

Department of Pharmacology,

Saveetha Dental College and Hospitals,

Saveetha University, Chennai-600 077,

INDIA.

\section{Correspondence}

\section{Ms. Anitha Roy}

Assistant Professor, Department of Pharmacology, Saveetha Dental College and Hospitals, Saveetha University, Chennai-600 077,

Tamil Nadu, INDIA.

Phone: (Off) 044-26801580-87

Mobile: + 91-9840787458

Fax: +91 4426800892

E-mail: anitharoy2015@gmail.com

\section{History}

- Submission Date: 26-06-2016;

- Review completed: 21-11-2016;

- Accepted Date: 22-11-2016.

\section{DOI : 10.5530/pj.2017.2.34}

\section{Article Available online}

http://www.phcogj.com/v9/i2

\section{Copyright}

(C) 2017 Phcog.Net. This is an openaccess article distributed under the terms of the Creative Commons Attribution 4.0 International license.

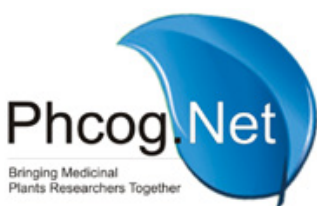

\begin{abstract}
Aim: The present study was designed to examine the cytotoxic effects of ethanolic leaf extract of Caralluma fimbriata in the COLO 320 cell line. Materials and Method: The anti-proliferative effects were evaluated using the MTT assay. The COLO 320 cells were treated with different concentrations of the leaf extract of Caralluma $(100-300 \mu \mathrm{g} / \mathrm{ml})$ for $24 \mathrm{~h}$. The cell viability and $I C_{50}$ was calculated from the cytotoxicity. The morphology of the Caralluma treated cells, control, and positive control were observed under reverse phase inverted microscope. Result: The C. fimbriata ethanolic leaf extract showed dose dependant increase in cytotoxicity in COLO 320 human colon cancer cells. The maximum cytotoxic effect was noticed with maximum dose used in this study i.e., $300 \mu \mathrm{g}$ with an $I C_{50}$ value of $233.87 \mu \mathrm{g}$. Conclusion: The present study shows that the ethanolic leaf extract of Caralluma fimbriata is capable of reducing cell proliferation by inducing cytotoxicity of COLO 320 cells.
\end{abstract}

Key words: Colonic cancer, COLO 320 cell line, Caralluma fimbriata, cytotoxicity, MTT Assay

\section{INTRODUCTION}

Human colon cancer is one of the leading causes of cancer death in both men and women worldwide and it is a clinically common, highly malignant tumor of the digestive tract. ${ }^{1}$ Currently, colon cancer is the third most common cancer type in humans, the fourth most common cause of death because of cancer, and the second most common cancer type in terms of the number of individuals living with cancer 5 years after diagnosis worldwide, approximately 694,000 people die from colon cancer annually. ${ }^{2}$ Diet contributes to $20 \%$ to $42 \%$ of all human cancers and $50 \%$ to $90 \%$ of colon cancer. $^{3}$ The risk factors associated may include a family history of cancer of the colon or rectum, hereditary conditions, such as familial adenomatous polyposis and hereditary nonpolyposis colon cancer, a history of ulcerative colitis or Crohn' s disease, personal history of cancer of the colon, rectum, ovary, endometrium, or breast, polyps in the colon or rectum. ${ }^{4}$

Normal treatment modality includes surgery, radiofrequency ablation, cryosurgery, chemotherapy, radiotherapy, targeted therapy with monoclonal antibodies, angiogenesis inhibitors. This is regardless of widespread, effective measures of preventive screening, and also major advances in treatment options. Due to an increasing rate of mortality associated with cancer and adverse or toxic side effects of cancer chemotherapy and radiation therapy, discovery of new anticancer agents derived from nature has begun especially plants and the screening of medicinal plants as a source of anticancer molecules. ${ }^{5}$ There is an overwhelming evidence of a preventive/protective role of dietary plant extracts, especially fruits, vegeta- bles, grains, and herbs, against colon cancer. Indeed, dietary intervention is emerging as an alternative to prevent the progression of colon cancer mainly due to its potency and reduced toxicity. ${ }^{3,6}$

Caralluma fimbriata is an edible succulent cactus and wild medicinal plant in the family Apocynaceae, growing in dry places, used by tribal Indians to suppress hunger and known as "famine food" with no history of adverse effects, which contains pregnane glycosides. ${ }^{7}$ This plant has been investigated for its myriad biological effects such as antihyperglycaemic and hypolipidaemic, hepatoprotective, antioxidant activity and came out with promising results. ${ }^{8-10}$ In light of above reports, it is reasonable to assume that this plant could have anticancer potential. Hence, in this study we investigated the cytotoxic potential of C. fimbriata ethanolic leaf extract against human COLO 320 cancer cell lines.

\section{MATERIALS AND METHODS}

\section{Reagents and Extract}

3-(4,5-dimethyl thiazol-2-yl)-5-diphenyl tetrazolium bromide (MTT), Trypan blue, foetal bovine serum (FBS), Phosphate Buffered Saline (PBS), Dulbecco's Modified Eagle's Medium (DMEM), Dimethylsulfoxide (DMSO), Cyclophosphamide were purchased from Sigma Chemical, USA and all other chemical used in this study purchased locally and were of analytical grade. The C. fimbriata ethanolic leaf extract was obtained from Green Chem. Herbal Extracts and Formulations, Bengaluru as gratis. 


\section{Cell culture}

The COLO 320 cells were cultured in DMEM supplemented with 10\% of fetal bovine serum and $1 \%$ penicillin-streptomycin. Cell cultures were maintained at $37^{\circ} \mathrm{C}$ in a fully humidified atmosphere containing $5 \% \mathrm{CO}_{2}$.

\section{Cell treatment}

C. fimbriata was dissolved in $0.1 \%$ DMSO (v/v). COLO 320 cells were plated at $1.2 \times 10^{4}$ cells $/ \mathrm{cm}^{2}$. Twenty-four hours later, cells were fed with fresh expansion culture medium supplemented with different final concentrations of extract $(100,200$ and $300 \mu \mathrm{g} / \mathrm{ml})$ or the corresponding volumes of the vehicle. After $24 \mathrm{~h}$ of treatment, cells were collected after $0.05 \%$ trypsin application. Cell viability was also evaluated by MTT assay.

\section{MTT assay}

The cells were plated in 96 well flat bottom tissue culture plates at a density of approximately $1.2 \times 10^{4}$ cells /well and allowed to attach overnight at $37^{\circ} \mathrm{C}$. The medium was then discarded and cells were incubated with different concentrations of the sample $(100,200 \& 300 \mu \mathrm{g} / \mathrm{ml})$ for 24 hours. After the incubation, medium was discarded and $100 \mu \mathrm{l}$ fresh medium was added with $10 \mu \mathrm{l}$ of MTT $(5 \mathrm{mg} / \mathrm{ml})$. After 4 hours, the medium was discarded and $100 \mu \mathrm{l}$ of DMSO was added to dissolve the formazan crystals. Then, the absorbance was read at $570 \mathrm{~nm}$ in a microtiter plate reader. Cyclophosphamide was used as positive control. The experiment was carried out in triplicate. The percentage cytotoxicity was plotted against different concentration and the $\mathrm{IC}_{50}$ values were determined.

\section{RESULTS}

\section{Cytotoxic assay}

In the present study, we evaluated the cytotoxic potential of C. fimbriata ethanolic leaf extract in COLO 320 cells by MTT assay. MTT assay was employed to assess the number of viable cells which has been adapted to measure the growth modulation of cells in vitro. The in vitro cytotoxicity assays offers quick, simple and cost-efficient way of testing the toxicity and forms. The COLO 320 cells were treated with different concentrations of the ethanolic leaf extract of carulloma $(100-300 \mu \mathrm{g} / \mathrm{m} 1)$ for 24 h. C. fimbriata ethanolic leaf extract caused dose dependant increase in cytotoxicity in COLO 320 human colon cancer cells. The maximum cytotoxic effect was noticed with maximum dose used in this study i.e., $300 \mu \mathrm{g}$ [Figure 1]. The ethanolic leaf extract of $C$. fimbriata demonstrated good antiproliferative activity against COLO 320 cells. The extract showed an inhibitory concentration $\left(\mathrm{IC}_{50}\right)$ is $233.87 \mu \mathrm{g}$ [Figure 2].

\section{Cell viability}

We noticed that $C$. fimbriata treatment in COLO 320 cells caused dose dependent fall in the cell viability. Cytotoxic activity was determined by cell viability and cell morphology was observed under the inverted microscope [Figure 3]. The ethanolic C. fimbriata leaf extract decreased the cell viability of colon cancer cells.

\section{DISCUSSION}

Colon cancer is one of the most dangerous forms of cancer, with invasive potential to spread to distinct parts of the body including liver, lung, ovaries and other gastrointestinal organs. Colon cancer is currently treated with 5 -flourouracil and oxaliplatin. ${ }^{11}$ However, while synthetic chemical anticancer drugs prolong survival, they often have adverse effects and off target actions. Accordingly, there is a need to develop novel drug therapies for colon cancer. ${ }^{12}$ Several plant derived compounds have studied for their anticancer effect and came with promising results. Naturaceuticals such as silibinin, quercetin, curcumin ${ }^{13-15}$ and plant extracts such as Curcuma longa, Moringa oleifera, Camellia sinensis, Dictyopteris undulata have also been tested for their anticancer effects against colon cancer. ${ }^{16-19}$ In previous studies $C$. fimbriata has been evaluated against several cancer models except colon cancer. Methanolic extract of the C. fimbriata reported to exhibit anti lung cancer activity, Priya et al. carried out cell viability and growth inhibition activity of the methanolic extract of C. fimbriata against A-549 lung cancer cell lines. ${ }^{20}$ In vitro cytotoxicity studies are commonly performed to evaluate the anticancer potentials of a drug or plant extracts. ${ }^{21}$ In this study, we noticed cytotoxic potential of C. fimbriata in human colon cancer cell line. Studies have reported the presence of phytophenol and flavonoids in the ethanolic extract of Carulloma fimbriata. ${ }^{20}$ C. fimbriata reported for appetite control, antiobesogenoic and other metabolic regulations. The appetite suppressing properties of $C$. fimbriata has been attributed to the active component, pregnane

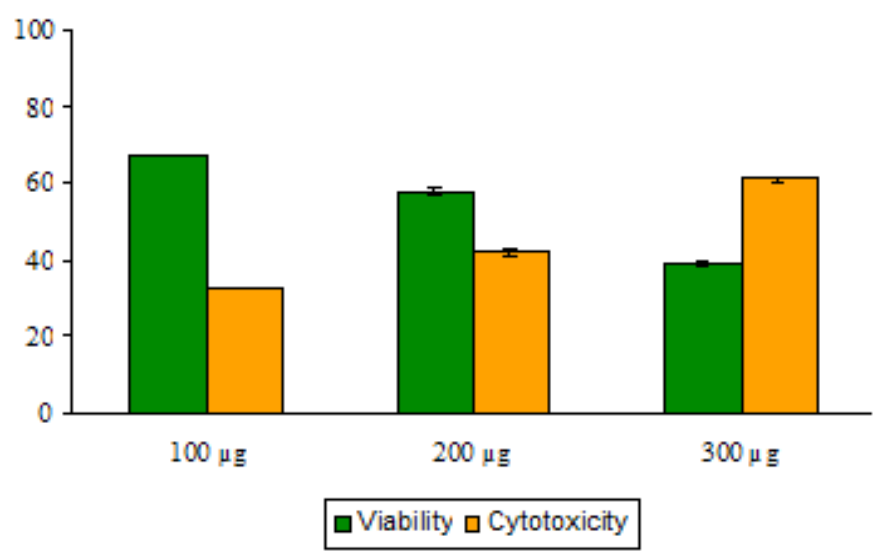

Figure 1: Determination cytotoxcity and viability of COLO 320 cells after $24 \mathrm{~h}$ treatment with Caralluma fimbriata by MTT assay $(n=3)$.

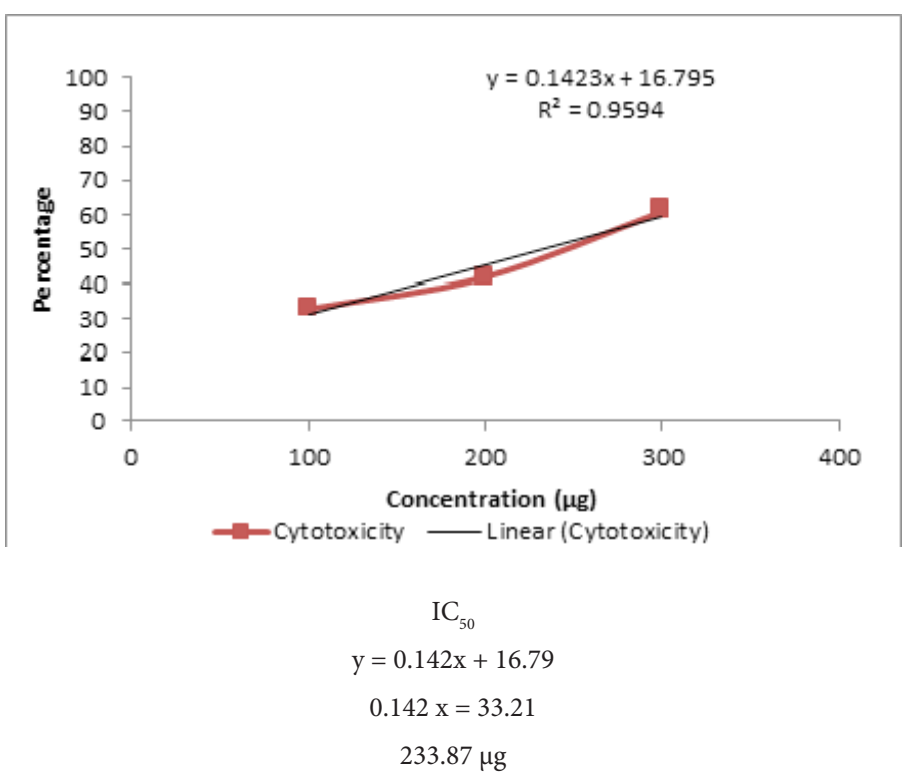

Figure 2: Linear graph showing $\mathrm{IC}_{50}$ of ethanolic leaf extract of $C$. fimbriata on cell viability in COLO320 cell line 


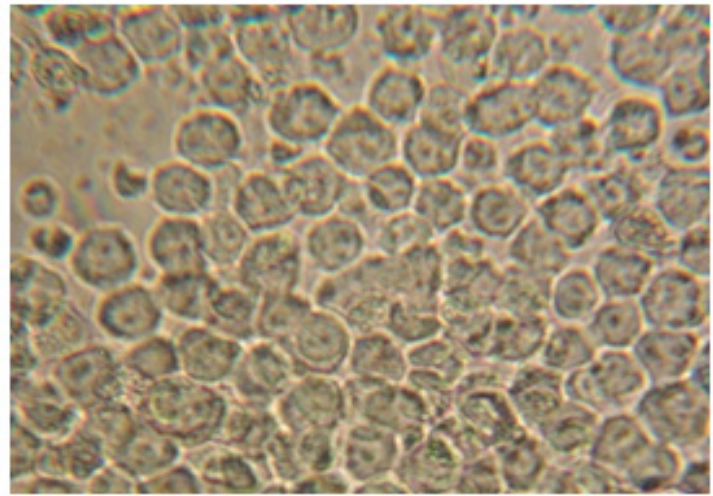

Control

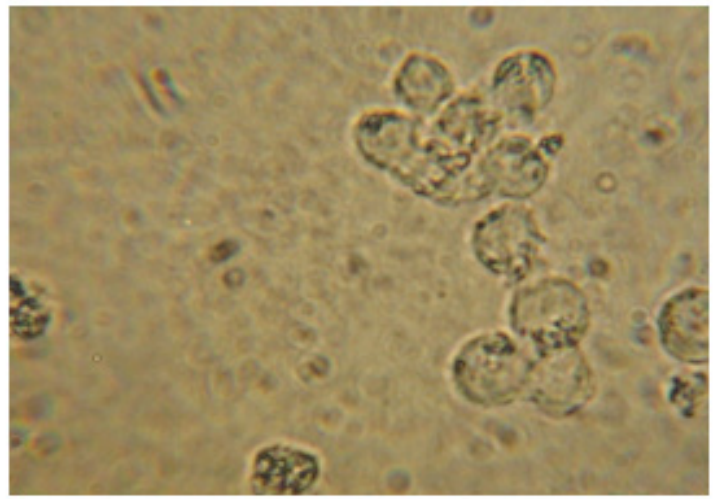

Positive Control (Cyclophosphamide)

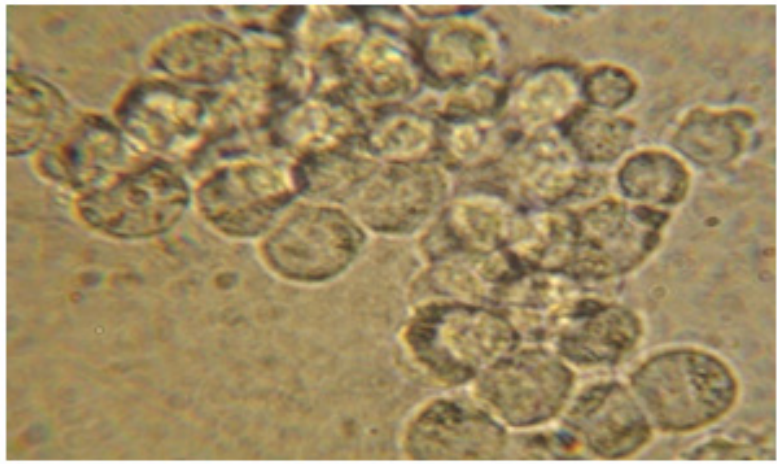

\section{Caralluma fimbriata treated cells $(300 \mu \mathrm{g})$}

Figure 3: Morphology of COLO 320 cells after $24 \mathrm{~h}$ treatment with Caralluma fimbriata (200x) Caralluma fimbriata treated cells $(300 \mu \mathrm{g})$

glycosides. ${ }^{22}$ Recently, this pregane glycoside has been reported to possess anti proliferative and anticancer effects against breast cancer cells. ${ }^{23}$ Currently, interest in polyphenols has been raised due to their reported chemo preventive and/or chemotherapeutic potential. ${ }^{24}$ In light of the above reports it is to suggest that the profound cytotoxic effect of C. fimbriata ethanolic leaf extract in human colon cells could be due presence of pregnane glycosides. The cytotoxic potential of $C$. fimbriata could be due to an induction of apoptosis. However, further studies are warranted on these lines to understand the molecular mechanism of cytotoxicity inducing potentials of C. fimbriata.

\section{ACKNOWLEDGEMENT}

Authors extend their heart felt thanks to Dr. R. Rajendran, CEO, Green Chem Bangalore for providing Caralluma fimbriata as gratis for this study

\section{CONFLICTS OF INTEREST}

None to declare

\section{REFERENCES}

1. Luo ZF, Zhao D, Li XQ, CuiYX, Ma N, Lu CX, et al. Clinical significance of HOTAIR expression in colon cancer. World J Gastro enterol. 2016;22(22):5254-9. http:// dx.doi.org/10.3748/wjg.v22.i22.5254 ;PMid:27298568 PMCid:PMC4893472.

2. Karanikas $M$, Esebidis $A$. Increasing incidence of colon cancer in patients $<50$ years old: a new entity? Ann Trans| Med. 2016;4(9):164. http://dx.doi. org/10.21037/atm.2016.04.13; PMid:27275477 PMCid:PMC4876259.

3. Kasdagly M, Radhakrishnan S, Reddivari L, Veeramachaneni DN, Vanamala J. Colon carcinogenesis: influence of Western diet-induced obesity and targeting stem cells using dietary bioactive compounds. Nutrition. 2014;30(11-12):1242-
56; http://dx.doi.org/10.1016/j.nut.2014.02.016; PMid:25280404.

4. Labianca R, Nordlinger B, Beretta GD, Brouquet A, Cervantes A. ESMO Guidelines Working Group. Primary colon cancer: ESMO Clinical Practice Guidelines for diagnosis, adjuvant treatment and follow-up. Ann On col. 2010;21(Supp 5):70-7. http://dx.doi.org/10.1093/annonc/mdq168; PMid:20555107.

5. Hammond WA, Swaika A, Mody K. Pharmacologic resistance in colorectal cancer: a review. Ther Adv Med Oncol. 2016;8(1):57-84. PMid:26753006 PMCid:PMC4699262

6. Jones DP, Park Y, Ziegler TR Nutritional meta bolomics: progress in address ing complexity in diet and health. Annual Review Nutrition. 2012;32:183-202. http://dx.doi.org/10.1146/annurev-nutr-072610-145159; PMid:22540256. PMCid: PMC4031100.

7. Kunert O, Rao VG, Babu GS, Sujatha P, Sivagamy M, Anuradha S, et al.Pregnane glycosides from Caralluma adscendens var. fimbriata. Chem Biodivers. 2008;5(2):239-50. http://dx.doi.org/10.1002/cbdv.200890021; PMid:18293437.

8. Abdel-Sattar E, Harraz FM, Ghareib SA, Elberry AA, Gabr S and Suliaman MI. Antihyperglycaemic and hypolipidaemic effects of the methanolic extract of Caralluma tuberculata in streptozotocin-induced diabetic rats. Nat Prod Res. 2011;25(12):1171-9. http://dx.doi.org/10.1080/14786419.2010.4907 82; PMid:21740282

9. Latha S, Rajaram K, Suresh Kumar P. Hepatoprotective and antidiabetic effect of methanol extract of Caralluma fimbriata in streptatozocin induced diabetic albino rats. Int J Pharm Pharm Sci. 2014;6(1):665-8.

10. Sudhakara G, Mallaiah P, Sreenivasulu N, Sasi Bhusana Rao B, Rajendran R and Saralakumari D. Beneficial effects of hydro-alcoholic extract of Caralluma fimbriata against high-fat diet-induced insulin resistance and oxidative stress in Wistar male rats. J Physiol Biochem. 2014;70(2):311-20. http://dx.doi.org/10.1007/ s13105-013-0304-1; PMid:24474087.

11. Raftery L, Goldberg RM. Optimal delivery of cytotoxic chemotherapy for colon cancer. Cancer J. 2010;16(3):214-9. http://dx.doi.org/10.1097/ PPO.0b013e3181ddc5ac; PMid:20526099.

12. Kuppusamy P, Yusoff MM, Maniam GP, Ichwan SJ, Soundharrajan I and Govindan N. Nutraceuticals as potential therapeutic agents for colon cancer: a review. Acta Pharm Sin B. 2014;4(3):173-81. http://dx.doi.org/10.1016/j. apsb.2014.04.002; PMid:26579381 PMCid:PMC4629076.

13. Sharma R. Nutraceuticals and nutraceutical supplementation criteria in cancer: 
a literature survey. Open Nutraceuticals J. 2009;2:92-106. http://dx.doi.org/10.2 174/1876396000902010092.

14. Chen JZ. Prevention of obesity-associated colon cancer by (-)-epigallocatechin-3 gallate and curcumin. Transl Gastrointest Cancer. 2012;1(3):243-9.

15. Shan BE, Wang MX, Li RQ. Quercetin inhibit human SW480 colon cancer growth in association with inhibition of cyclin D1 and survivin expression through Wnt/beta-catenin signaling pathway. Cancer Invest. 2009;27(6):604-12. http://dx.doi.org/10.1080/07357900802337191; PMid:19440933.

16. Dimas K, Tsimplouli C, Houchen C, Pantazis P, Sakellaridis N, Tsangaris GT,et al. An Ethanol Extract of Hawaiian Turmeric: Extensive In Vitro Anticancer Activity Against Human Colon Cancer Cells. Altern Their Health Med. 2015;21(Suppl 2):46-54; PMid:26308760.

17. Al-Asmari AK, Albalawi SM, Athar MT, Khan AQ, Al-Shahrani H, Islam M. Moringa oleifera as an Anti-Cancer Agent against Breast and Colorectal Cancer Cell Lines. PLoS One. 2015;19;10(8):e0135814.

18. Hajiaghaalipour F, Kanthimathi MS, Sanusi J, Rajarajeswaran J. White tea (Camellia sinensis) inhibits proliferation of the colon cancer cell line, HT-29, activates caspases and protects DNA of normal cells against oxidative damage. Food Chem. 2015;169:401-10. http://dx.doi.org/10.1016/j.foodchem.2014.07.005; PMid:25236244.

19. Kang KA, Kim JK, Jeong YJ, Na SY, Hyun JW. Dictyopteris undulata Extract In- duces Apoptosis via Induction of Endoplasmic Reticulum Stress in Human CoIon Cancer Cells. J Cancer Prev. 2014;19(2):118-24. http://dx.doi.org/10.15430/ JCP.2014.19.2.118; PMid:25337580 PMCid:PMC4204170.

20. Priya D, Rajaram K and SureshKumar P. Phytochemical studies and GCMS analysis of Caralluma fimbriata wall. Int J Pharm Res Dev. 2011;10:105-110.

21. Riss TL, Moravec RA, Niles AL. Cytotoxicity testing: measuring viable cells, dead cells, and detecting mechanism of cell death. Methods Mol Biol. 2011;740:10314. http://dx.doi.org/10.1007/978-1-61779-108-6_12; PMid:21468972.

22. Kamalakkannan S, Rajendran R, Venkatesh RV, Clayton P, Akbarsha MA. Antiobesogenic and Antiatherosclerotic Properties of Caralluma fimbriata Extract. J Nutr Metab. 2010:285301. http://dx.doi.org/10.1155/2010/285301; PMid:21234320. PMCid:PMC3018644.

23. Hussain $\mathrm{H}$, Raees MA, Rehman NU, Al-Rawahi A, Csuk $\mathrm{R}$, Khan HY, et al. Nizwaside: a new anticancer pregnane glycoside from the sap of Desmidorchis flava. Arch Pharm Res. 2015;38(12):2137-42. http://dx.doi.org/10.1007/s12272015-0653-0; PMid:26335549.

24. Turrini E, Ferruzzi L, Fimognari C. Potential Effects of Pomegranate Polyphenols in Cancer Prevention and Therapy. Oxid Med Cell Longev. 2015:938475. http:// dx.doi.org/10.1155/2015/938475; PMid:26180600 PMCid:PMC4477247.

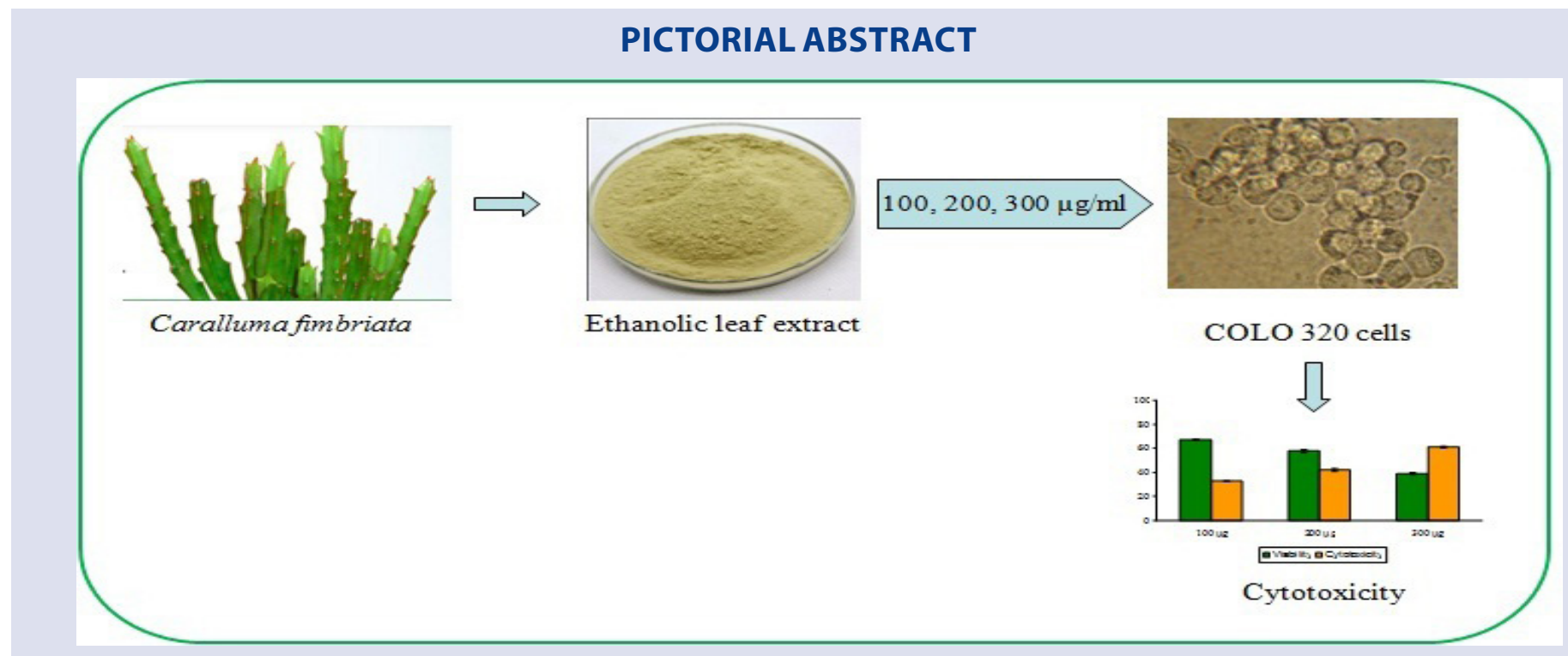

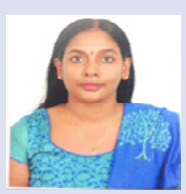

ABOUT AUTHORS

Ms Anitha Roy has completed her M.Pharm from Dr. Hari Singh Gour Vishwa Vidyalaya, Sagar, MP. She is pursuing for her Ph.D at Saveetha University. She is Presently working as Assistant Professor in the Department of Pharmacology at Saveetha Dental College and Hospitals. She has published about 50 papers in reputed journals

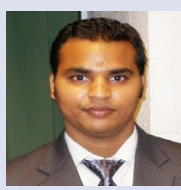

Dr. D. Ezhilarasan has completed his Ph.D from Dr. ALM PG Institute of Basic Medical Sciences, University of Madras, Chennai, India. Currently, he is working as Assistant Professor in Pharmacology, Saveetha Dental College and Hospitals, Saveetha University. He is an active researcher (https://scholar.google.co.in/citations?user=e4kSKvMAAAAJ\&hl=en) and his research interests include cancer biology, chronic liver diseases, pharmacognosy and cell signalling.

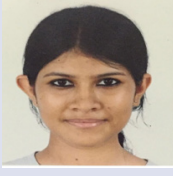

Ms Ashwini Shenai is currently doing her Bachelor's Degree in Dental Surgery at Saveetha Dental College and Hospitals, Chennai ,India. She is a bright student and has keen interest in academic as well as research activity. This work was carried out as a short term project as part of her graduation programme.

Cite this Article: Ashwini S, Ezhilarasan D, Anitha R. Cytotoxic Effect of Caralluma fimbriata Against Human Colon Cancer Cells. Pharmacogn J. 2017;9(2):2047 . 